\title{
Acaricidal activity of essential oils of Cinnamomum zeylanicum and Eremanthus erythropappus, major compounds and cinnamyl acetate in Rhipicephalus microplus
}

\author{
Atividade acaricida dos óleos essenciais de Cinnamomum zeylanicum e \\ Eremanthus erythropappus, compostos majoritários e acetato de cinamila \\ sobre Rhipicephalus microplus \\ Paula Marchesini* (D); Débora Ramos de Oliveira²; Geovany Amorim Gomes³; Tigressa Helena Soares \\ Rodrigues ${ }^{3}$; Ralph Maturano4; Queli Cristina Fidelis'; Francisco Eduardo Aragão Catunda Júnior ${ }^{6}$; \\ Mário Geraldo de Carvalho²; Vânia Rita Elias Pinheiro Bittencourt' ${ }^{\text {; }}$ Caio Márcio Oliveira Monteiro ${ }^{7}$
}

\footnotetext{
1Programa de Pós-graduação em Ciências Veterinárias, Universidade Federal Rural do Rio de Janeiro - UFRRJ, Seropédica, RJ, Brasil 2Departamento de Química, Instituto de Ciências Exatas, Universidade Federal Rural do Rio de Janeiro - UFRRJ, Seropédica, RJ, Brasil ${ }^{3}$ Centro de Ciências Exatas e Tecnologia, Universidade Estadual do Vale do Acaraú - UVA, Sobral, CE, Brasil 4Programa de Pós-graduação em Ciências Biológicas, Universidade Federal de Juiz de Fora - UFJF, Juiz de Fora, MG, Brasil ${ }^{5}$ Departamento de Ciências e Tecnologia, Universidade Federal do Maranhão - UFMA, Balsas, MA, Brasil

${ }^{6}$ Centro de Ciências Exatas, Naturais e Tecnológicas, Universidade Estadual da Região Tocantina do Maranhão - UEMASUL, Imperatriz, MA, Brasil

${ }^{7}$ Instituto de Patologia Tropical e Saúde Pública, Universidade Federal de Goiás - UFG, Goiânia, GO, Brasil
}

How to cite: Marchesini P, Oliveira DR, Gomes GA, Rodrigues THS, Maturano R, Fidelis QC, et al. Acaricidal activity of essential oils of Cinnamomum zeylanicum and Eremanthus erythropappus, major compounds and cinnamyl acetate in Rhipicephalus microplus. Braz J Vet Parasito/ 2021; 30(3): e009221. https://doi.org/10.1590/S1984-29612021070

\begin{abstract}
This study aimed to chemically characterize the essential oils (EOs) of Cinnamomum zeylanicum (cinnamon) and Eremanthus erythropappus (candeia) and evaluate their acaricidal activity, together with that of their major compounds and cinnamyl acetate derivative, against Rhipicephalus microplus. Essential oil compounds were identified through gas chromatography. The larval packet test (LPT) at concentrations ranging from 0.31 to $10.0 \mathrm{mg} / \mathrm{mL}$ and the adult immersion test (AIT) at concentrations between 2.5 and $60.0 \mathrm{mg} / \mathrm{mL}$ were performed. (E)-cinnamaldehyde and a-bisabolol were the major compounds in cinnamon (86.93\%) and candeia (78.41\%) EOs, respectively. In the LPT, the EOs of cinnamon and candeia and the compounds (E)-cinnamaldehyde, a-bisabolol and cinnamyl acetate resulted in $100 \%$ mortality at concentrations of $2.5,2.5,5.0,10.0$ and $10.0 \mathrm{mg} / \mathrm{mL}$ respectively. In the AIT, percentage control values $>95 \%$ were observed for cinnamon and candeia EOs, (E)-cinnamaldehyde and a-bisabolol at the concentrations of 5.0, $60.0,20.0$, and $20.0 \mathrm{mg} / \mathrm{mL}$, respectively, whereas cinnamyl acetate showed low activity. We conclude that EOs and their compounds showed high acaricidal activity, whereas the acetylated derivative of (E)-cinnamaldehyde presented less acaricidal activity on $R$. microplus engorged females.
\end{abstract}

Keywords: Cattle tick, cinnamon, candeia, (E)-cinnamaldehyde, a-bisabolol.

\section{Resumo}

Este estudo teve como objetivo caracterizar quimicamente os óleos essenciais (OE) de Cinnamomum zeylanicum (canela) e Eremanthus erythropappus (candeia) e avaliar sua atividade acaricida, juntamente com a de seus principais compostos e do derivado de acetato de cinamila, sobre Rhipicephalus microplus. Os compostos do óleo essencial foram identificados por cromatografia gasosa. Foram realizados o Teste de Pacote de Larvas (TPL), em concentrações variando de 0,31 a 10,0 mg/mL, e o Teste de Imersão de Adultos (TIA), em concentrações entre 2,5 e $60,0 \mathrm{mg} / \mathrm{mL}$. (E)-cinnamaldeído e a-bisabolol foram os principais compostos nos OE da canela $(86,93 \%)$ e da candeia $(78,41 \%)$, respectivamente. No TPL, os OEs de canela e candeia, e os compostos (E)-cinnamaldeído, a-bisabolol e

Received May 20, 2021. Accepted July 19, 2021.

*Corresponding author: Paula Marchesini. E-mail: paulabarrosocruz@hotmail.com 
acetato de cinamila resultaram em $100 \%$ de mortalidade nas concentrações de 2,5, 2,5, 5,0, 10,0 e 10,0 mg/mL, respectivamente. No TIA, valores percentuais de controle $>95 \%$ foram observados para OE de canela e candeia, (E)-cinnamaldeído e a-bisabolol nas concentrações de 5,0,60,0, 20,0 e 20,0 mg/mL, respectivamente, enquanto o acetato de cinamila apresentou baixa atividade. Conclui-se que os OEs e seus compostos apresentaram alta atividade acaricida, enquanto o derivado acetilado do $(E)$-cinnamaldeído apresentou menor atividade acaricida em fêmeas ingurgitadas de $R$. microplus.

Palavras-chave: Carrapatos dos bovinos, canela, candeia, (E)-cinamaldeído, (a)-bisabolol.

\section{Introduction}

Rhipicephalus microplus (Canestrini, 1888), also known as the cattle tick, can cause several types of harm to livestock. In addition, this species is a limiting factor for the productive success of cattle raising (Labruna \& Machado, 2006; Furlong et al., 2007). The annual economic losses caused by this ectoparasite in Brazil can reach US\$ 3.24 billion (Grisi et al., 2014), while the annual losses estimated worldwide range from US\$22 to 30 billion (Lew-Tabor \& Rodriguez Valle, 2016).

Currently, the main tick control method consists of use of synthetic acaricides. These provide relatively fast and cost-effective suppression of populations and are easily available on the market (Abbas et al., 2014). However, continuous use of these products can lead to issues such as environmental contamination, residues in milk and meat, and development of resistant tick populations (Graf et al., 2004). These issues have motivated the development of new tick control technologies (Zaman et al., 2012).

Studies have shown that essential oils (EOs) extracted from aromatic plants are an ecologically sustainable (eco-friendly) alternative with potential for use in tick control. Among the characteristics of EOs that favor their use, it is worth emphasizing the fact that they derive from renewable resources, delay the selection of resistant populations because they present a complex mixture of compounds, and present lower risk of environmental and animal harm because of their high biodegradability rates and low toxicity in mammals (Borges et al., 2011; Madzimure et al., 2011; Liu et al., 2017).

Species of the Asteraceae and Lauraceae families are among the plants from which EOs with potential for tick control can be extracted. Cinnamomum zeylanicum Blume (cinnamon) (synonym - Cinnamomum verum) is a plant of the Lauraceae family from which the essential oil has been successfully tested for biological activity against bacteria (Mishra et al., 2008), fungi (Carmo et al., 2008), insects (Yang et al., 2005) and ticks (Monteiro et al., 2017; Jyoti et al., 2019; Nwanade et al., 2021). (E)-cinnamaldehyde is the main constituent in the essential oil extracted from C. zeylanicum bark. This phenylpropanoid presents activity against bacteria and arthropods (Shen et al., 2012; Senra et al., 2013; Novato et al., 2015).

Eremanthus erythropappus (DC.) MacLeish (candeia) (synonym - Vanillosmopsis erythropappa) is a Brazilian native tree species of the Asteraceae family whose essential oil presents biological activity against fungi (Teixeira et al., 2015). However, no reports on its acaricidal activity are known. E. erythropappus essential oil is the main source of a-bisabolol, which is a sesquiterpene that presents activity against bacteria (Kamatou \& Viljoen, 2010), inflammatory diseases (Leite et al., 2011) and cancer (Kamatou \& Viljoen, 2010).

Studies focused on investigating structural modifications in substances extracted from EOs, based on changes in functional groups, have been conducted in order to enhance the biological activity or increase the biosafety of these compounds (Kim et al., 2015). These changes include the acetylation process based on introduction of an acetate group. This process, which replaces the hydroxyl group $(-\mathrm{OH})$ with the acetate group, provides molecules with greater cuticular permeability, thus facilitating absorption into the arthropod (Lanusse \& Prichard, 1993). In addition, it is less toxic to mammals (André et al., 2016, 2017), which makes its acaricidal use safer both for animals and for the environment. According to some studies, the acetylation process can increase the activity of these compounds on bacteria, insects and ticks (Mathela et al., 2010; Scotti et al., 2014, Ramírez et al., 2016).

The aims of the present study were to chemically characterize the EOs extracted from E. erythropappus stems and $C$. zeylanicum bark; and to evaluate the acaricidal activity of these oils, their major compounds and the $(E)$ cinnamaldehyde acetylated derivative (= cinnamyl acetate) against unfed larvae and engorged females of $R$. microplus. 


\section{Materials and Methods}

\section{Essential oils and compounds}

Eremanthus erythropappus essential oil, obtained by means of steam distillation from the stem of this plant species cultivated in the state of Minas Gerais (MG), was kindly supplied by Atina - Ativos Natural - Ltda (Pouso Alegre, MG, Brazil). C. zeylanicum essential oil was acquired commercially from Laszlo ${ }^{\circledR}$ (Belo Horizonte, MG, Brazil); the oil of this plant, which originates from Sri Lanka, was obtained by steam distillation of the plant bark. The a-bisabolol (95\% purity) was kindly provided by Citróleo Indústria e Comercio Ltda (Torrinha, SP, Brazil), while (E)-cinnamaldehyde and cinnamyl alcohol (98\% purity) (used for production of cinnamyl acetate) (Figure 1) were purchased from Sigma-Aldrich (St Louis, MO, USA).

A<smiles>O=C/C=C/c1ccccc1</smiles>

B

\section{C}

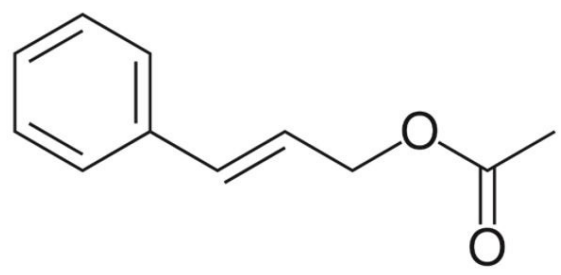

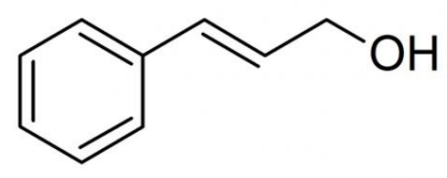

Figure 1. Chemical structure of (E)-cinnamaldehyde (A), cinnamyl alcohol (B) and cinnamyl acetate (C).

\section{Chemical analysis of essential oils}

The EOs were subjected to qualitative analysis of their chemical composition through gas chromatography coupled with mass spectrometry (GC/MS) using the Shimadzu GC-2010 device (quadrupole) with the following characteristics: electron impact at $70 \mathrm{eV}$; RTX-5MS methylpolysiloxane column (30 m x $0.25 \mathrm{~mm} \times 0.25 \mu \mathrm{m}$; Restek®); 1:100 split injection mode; helium carrier gas flow rate of $1.00 \mathrm{~mL} / \mathrm{min}$; and the following temperatures: injector $250^{\circ} \mathrm{C}$, transfer line $250^{\circ} \mathrm{C}$ and ion source $230^{\circ} \mathrm{C}$. The gas chromatography oven was programmed as follows: initial temperature of $70^{\circ} \mathrm{C}$; heating ramp of $4^{\circ} \mathrm{C} / \mathrm{min}$ up to $180^{\circ} \mathrm{C}$; and temperature increase rate of $10^{\circ} \mathrm{C} / \mathrm{min}$ up to $250^{\circ} \mathrm{C}$ at the end of the run (34.5 min).

The quantitative analysis applied to the chemical composition of the EOs was performed through gas chromatography coupled to flame ionization detection (CG/FID) using a Shimadzu GC-2010 Plus spectrometer set up as follows: RTX-5 methylpolysiloxane column (30 $\mathrm{m} \times 0.25 \mathrm{~mm} \times 0.25 \mu \mathrm{m})$; split injection mode (1:30); nitrogen carrier gas flow rate of $1.00 \mathrm{~mL} / \mathrm{min}$; injector temperature $250{ }^{\circ} \mathrm{C}$; and detector temperature $280{ }^{\circ} \mathrm{C}$. The gas chromatography oven was programed as in the GC/MS analysis.

Percentages of the chemical constituents of the EOs were calculated based on the integral area of their respective peaks, in comparison with the total area of all sample constituents. Several essential oil constituents were identified by visually comparing their mass spectra with those reported in the literature (Bohlmann et al., 1998; Adams, 2009) and with the spectra provided by the equipment database (NIST08), as well as by making comparisons with the retention indices available in the literature (Adams, 2009; El-Sayed, 2018). An $n$-alkane standard solution (C7-C30) was injected under the same chromatographic conditions as that of the sample, in order to find retention rates, as described by van Den Dool \& Kratz (1963). 


\section{Acetylated derivative preparation}

The $(E)$-cinnamaldehyde acetylation process was performed at the Natural Products Laboratory of the Federal Rural University of Rio de Janeiro (UFRRJ), based on the descriptions of Oliveira et al. (1999). To this end, cinnamyl alcohol $(4.44 \mathrm{~g})$, acetic anhydride $(8.88 \mathrm{~mL})$ and pyridine $(6.66 \mathrm{~mL})$ were added to a $25 \mathrm{~mL}$ flask. Reagents were placed under stirring with the aid of a magnetic stirrer equipped with a stirring plate, for $24 \mathrm{~h}$. The product from the reaction was added with chloroform. The residual solution was washed with hydrochloric acid (10\%) until all pyridine had been removed from the system through soluble salt formation.

\section{Acetylation product confirmation}

Nuclear magnetic resonance (NMR) (1D) spectrum analyses were performed using a Bruker AVANCE II 11.5 T spectrometer $\left(500 \mathrm{MHz}\right.$ for ${ }^{1} \mathrm{H}$ and $125 \mathrm{MHz}$ for ${ }^{13} \mathrm{C}$ ) at the analytical center of the Chemistry Institute, Federal Rural University of Rio de Janeiro for product confirmation purposes. Tetramethylsilane (TMS) was used as the internal standard for chemical shift reference. Chemical shifts $(\delta)$ were expressed in parts per million (ppm), while coupling constants (J) were expressed in Hertz ( $\mathrm{Hz})$. Deuterated chloroform $\left(\mathrm{CDCl}_{3}\right)$ was used as the solvent in the NMR analysis.

\section{Ticks}

Ticks were collected from naturally infested cattle on farms in Minas Gerais, Brazil, and were provided by the Laboratório de Parasitologia da Empresa Brasileira de Pesquisa Agropecuária (Embrapa Gado de Leite), located in the municipality of Juiz de Fora, state of Minas Gerais, Brazil.

Half of the R. microplus engorged females were used to perform the adult immersion test (AIT), while the other fraction was stored in a climatized chamber with controlled temperature and relative humidity $\left(27 \pm 1^{\circ} \mathrm{C}\right.$ and $\mathrm{RH}$ of $80 \pm 10 \%$ ) for 15 days until oviposition. After this stage, the egg mass was weighed into $200 \mathrm{mg}$ aliquots and packed into syringes with a closed distal end, which were sealed using cotton wool. These eggs were then kept under the same aforementioned temperature and humidity conditions. Between 15 and 21 days after hatching, the larvae were used to perform LPT. The same tick population was used for the AIT and LPT tests on the same oil or compound.

\section{Larval Packet Test (LPT)}

For the LPT, the EOs, major compounds and cinnamyl acetate were diluted in $70 \%$ ethanol (water-ethanol, v/v) and a-bisabolol was diluted in $50 \%$ ethanol (water-ethanol v/v) at the concentrations of $0.31,0.62,1.25,2.0,2.5$, 5.0 and $10.0 \mathrm{mg} / \mathrm{mL}$. These concentrations and solvents were determined from studies on EOs in the literature (Senra et al., 2013; Diniz, 2014).

The LPT proposed by Stone \& Haydock (1962) and adapted by Monteiro et al. (2012) was used to assess the activity of the EOs and their major compounds. Approximately 100 unfed larvae were placed in the center of a filter paper ( $6 \mathrm{~cm} \times 6 \mathrm{~cm}$; Whatman no. 1), which was then folded in half and closed at the sides using binder clips. Next, each side of the filter paper was moistened with $90 \mu \mathrm{L}$ of test solutions ( $180 \mu \mathrm{L}$ in total). A control group was also formed ( $70 \%$ or $50 \%$ ethanol), and 10 replications were performed for each group.

The packets were then stored in a B.O.D. incubator at $27 \pm 1{ }^{\circ} \mathrm{C}$ and $\mathrm{RH}$ of $80 \pm 10 \%$ for $24 \mathrm{~h}$. After this period, the living and dead larvae were counted.

\section{Adult Immersion Test (AIT)}

For the AIT, groups of 10 engorged females (each female $=1$ experimental unit) presenting homogeneous weights $(p>0.05)$ were immersed at concentrations of $2.5,5.0,10.0,20.0,40.0$ and $60.0 \mathrm{mg} / \mathrm{mL}(10$ per concentration) for $5 \mathrm{~min}$. Concentrations were selected through preliminary tests and dimethyl sulfoxide (DMSO) at 3\% (water + DMSO, v/v) was used as the solvent. After immersion, each female was weighed individually and placed on a Petri dish $(6 \times 6 \mathrm{~cm})$ for oviposition. The groups were kept in a climate-controlled chamber under the aforementioned conditions for reproductive biology assessment. The following biological parameters were evaluated: female weight before oviposition (soon after treatment), egg mass weight (15 days after treatment) and larval hatching ( 21 days after egg mass weighing). From these values, the percentage control was calculated as described by Drummond et al. (1973). 


\section{Statistical analysis}

The statistical analyses conducted on both tests were carried out using the Biostat 5.3 software (Ayres et al., 2007). Treatments were compared by means of analysis of variance (ANOVA) followed by Tukey's test. Non-normally distributed data were subjected to the Kruskal-Wallis test followed by the Student-Newman-Keuls test. Probit analysis was performed using the $R$ software (version $3.5 .3,2019)$ to enable calculation of the lethal concentration $50\left(\mathrm{LC}_{50}\right)$.

\section{Results}

\section{Chemical composition of essential oils}

The essential oil extracted from C. zeylanicum bark showed predominance of phenylpropanoids (94.06\%), with (E)-cinnamaldehyde (86.93\%) as the major compound. In the chemical analysis on E. erythropappus stem essential oil, oxygenated sesquiterpenes (82.19\%) and sesquiterpene hydrocarbons (13.17\%) were identified, and sesquiterpene a-bisabolol was the major compound (78.41\%) (Table 1).

Table 1. Chemical composition, calculated Kovats index $\left(\mathrm{KI}_{\mathrm{C}}\right)$, Kovats index obtained from the literature $\left(\mathrm{KI}_{\mathrm{Lit}}\right)\left(\mathrm{Bohlmann}_{\mathrm{m}}\right.$ et al., 1998; Adams, 2009), percentages of identified compounds and chemical classes (\%) in the essential oils of Cinnamomum zeylanicum bark and Eremanthus erythropappus stem.

\begin{tabular}{|c|c|c|c|c|c|c|}
\hline \multirow[t]{2}{*}{ Components } & \multicolumn{3}{|c|}{ Cinnamomum zeylanicum } & \multicolumn{3}{|c|}{ Eremanthus erythropappus } \\
\hline & $\mathrm{KI}_{\mathrm{c}}$ & $\mathrm{KI}_{\text {Lit }}$ & (\%) & $\mathrm{KI}_{\mathrm{c}}$ & $\mathbf{K I}_{\text {Lit }}$ & (\%) \\
\hline Aromatic aldehyde & & & 3.71 & - & - & - \\
\hline Benzaldehyde & 966 & 960 & 3.71 & - & - & - \\
\hline Phenylpropanoids & & & 94.06 & - & - & - \\
\hline (E)-Cinamaldehyde & 1280 & 1270 & 86.93 & - & - & - \\
\hline $\begin{array}{c}(E) \text {-o-Methoxy } \\
\text { cinnamaldehyde }\end{array}$ & 1537 & 1528 & 7.13 & - & - & - \\
\hline Saturated fatty acid & - & - & - & & & 1.10 \\
\hline Isovaleric acid & - & - & - & 849 & 835 & 1.10 \\
\hline Sesquiterpene Hydrocarbons & & & & & & 13.17 \\
\hline$y$-curcumin & - & - & - & 1483 & 1482 & 0.61 \\
\hline$\beta$-selinene & - & - & - & 1486 & 1490 & 0.25 \\
\hline a-selinene & - & - & - & 1496 & 1498 & 0.27 \\
\hline (Z)-a-bisabolene & - & - & - & 1505 & 1504 & 3.36 \\
\hline$\beta$-bisabolene & - & - & - & 1513 & 1505 & 1.86 \\
\hline (E)-y-bisabolene & - & - & - & 1517 & 1531 & 0.95 \\
\hline (E)-a-bisabolene & - & - & - & 1547 & 1547 & 5.87 \\
\hline Oxygenated Sesquiterpenes & & & & & & 82.19 \\
\hline 2, (7Z)-bisaboladien-4-ol & - & - & - & 1627 & 1619 & 0.29 \\
\hline a-bisabolol B oxide & - & - & - & 1664 & 1658 & 1.72 \\
\hline (E)-bisabol-11-ol & - & - & - & 1675 & 1668 & 1.77 \\
\hline a-bisabolol & - & - & - & 1700 & 1685 & 78.41 \\
\hline Total Identified & & & 97.77 & & & 96.46 \\
\hline
\end{tabular}




\section{Acetylation confirmation}

The hydrogen (1 $\left.{ }^{1} \mathrm{HMR}\right)$ and carbon-13 $\left({ }^{13} \mathrm{C}\right.$ NMR) nuclear magnetic resonance (NMR) spectra that were used to confirm the acetylated product are shown in Figure 2. The final product was weighed and presented a mass of $5.25 \mathrm{~g}$, with $90 \%$ yield.

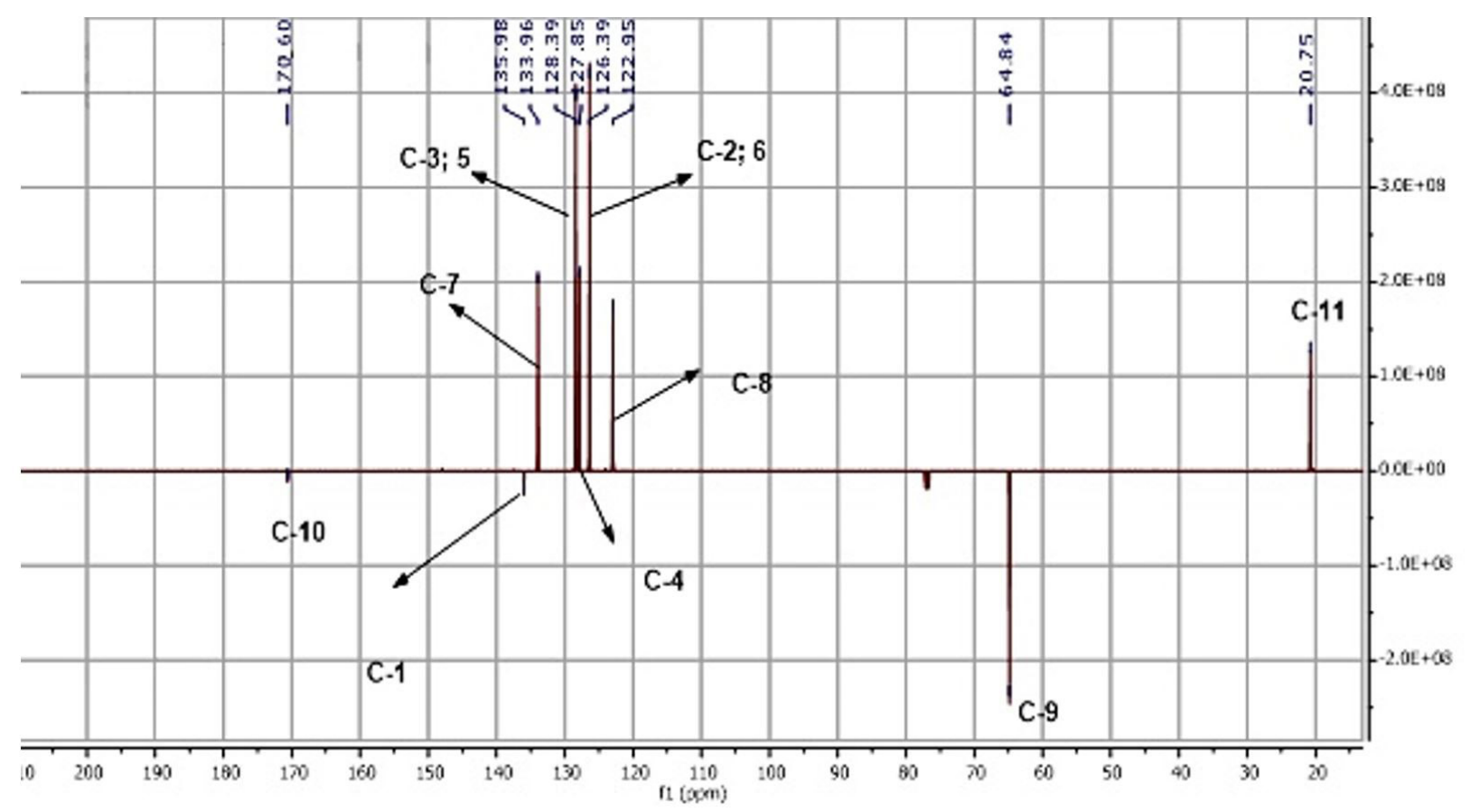

Figure 2. $\mathrm{RMN}{ }^{13} \mathrm{C}$ spectrum $\left(125 \mathrm{MHz} ; \mathrm{CDCl}_{3}\right)$ of cinnamyl acetate.

\section{Larval packet test}

The essential oil extracted from C. zeylanicum bark at the concentration of $1.25 \mathrm{mg} / \mathrm{mL}$ resulted in a $64.0 \%$ tick mortality rate, with a difference $(p<0.05)$ in comparison with control groups $(0.0 \%)$. The mortality rate was $>95 \%$ from the concentration of $2.0 \mathrm{mg} / \mathrm{mL}$ and reached $100.0 \%$ at the concentration of $2.5 \mathrm{mg} / \mathrm{mL}$ (Table 2). $(E)$-cinnamaldehyde resulted in mortality of larvae with differences $(p<0.05)$ in relation to the control groups, starting from the concentration of $1.25 \mathrm{mg} / \mathrm{mL}(29.2 \%)$. Larval mortality $>95 \%$ was observed from the concentration of $2.5 \mathrm{mg} / \mathrm{mL}$. However, only the highest concentration $(5.0 \mathrm{mg} / \mathrm{mL})$ resulted in a $100.0 \%$ larval mortality rate. Cinnamyl acetate at the concentration of $2.0 \mathrm{mg} / \mathrm{mL}$ led to $44.0 \%$ larval mortality, which was different from the mortality rate observed for the control groups $(p<0.05)$. At the highest concentrations $(5.0$ and $10.0 \mathrm{mg} / \mathrm{mL})$, mortality was 99.0 and $100.0 \%$, respectively (Table 2 ).

Eremanthus erythropappus essential oil resulted in mortality $>90 \%$ from the concentration of $2.0 \mathrm{mg} / \mathrm{mL}$ and reached $100.0 \%$ larval mortality at the concentration of $2.5 \mathrm{mg} / \mathrm{mL}$, with differences $(p<0.05)$ in comparison with the control groups (0.0\%). The a-bisabolol at the concentration of $2.0 \mathrm{mg} / \mathrm{mL}$ led to a larval mortality rate of $32.1 \%$, which was different $(p<0.05)$ from that observed in the control groups. Mortality rates $>95 \%$ were observed starting from the concentration of $5.0 \mathrm{mg} / \mathrm{mL}$ (96.7\% mortality), and reached $100.0 \%$ mortality at the concentration of $10.0 \mathrm{mg} / \mathrm{mL}$ (Table 2).

The $\mathrm{LC}_{50}$ values for $C$. zeylanicum, (E)-cinnamaldehyde, cinnamyl acetate, E. erythropappus and a-bisabolol used against $R$. microplus larvae were $0.94,1.38,2.31,1.61$ and $2.20 \mathrm{mg} / \mathrm{mL}$, respectively. Confidence interval overlaps were observed between (E)-cinnamaldehyde and E. erythropappus essential oil, as well as between cinnamyl acetate and a-bisabolol (Table 3). 
Table 2. Percentage of mean mortality of Rhipicephalus microplus unfed larvae treated with different concentrations of Cinnamomum zeylanicum, (E)-cinnamaldehyde, cinnamyl acetate, Eremanthus erythropappus and a-bisabolol under laboratory conditions $\left(27 \pm 1^{\circ} \mathrm{C}\right.$ and $\left.\mathrm{RH} 80 \pm 10 \%\right)$ (Mean \pm standard deviation).

\begin{tabular}{|c|c|c|c|c|c|}
\hline Treatments & $\begin{array}{c}\text { Cinnamomum } \\
\text { zeylanicum }\end{array}$ & $\begin{array}{c}(E)- \\
\text { cinnamaldehyde }\end{array}$ & Cinnamyl acetate & $\begin{array}{l}\text { Eremanthus } \\
\text { erythropappus }\end{array}$ & a-bisabolol \\
\hline Control - $\mathrm{H}_{2} \mathrm{O}$ & $0.0^{a} \pm 0.0$ & $0.0^{\mathrm{a}} \pm 0.0$ & $0.0^{\mathrm{a}} \pm 0.0$ & $0.0^{\mathrm{a}} \pm 0.0$ & $0.0^{\mathrm{a}} \pm 0.0$ \\
\hline Control -Solvent* & $0.0^{\mathrm{a}} \pm 0.0$ & $0.0^{\mathrm{a}} \pm 0.0$ & $0.0^{\mathrm{a}} \pm 0.0$ & $0.0^{\mathrm{a}} \pm 0.0$ & $0.0^{\mathrm{a}} \pm 0.0$ \\
\hline $0.31 \mathrm{mg} / \mathrm{mL}$ & $0.0^{\mathrm{a}} \pm 0.0$ & $0.0^{\mathrm{a}} \pm 0.0$ & $0.0^{\mathrm{a}} \pm 0.0$ & $0.0^{\mathrm{a}} \pm 0.0$ & $0.0^{\mathrm{a}} \pm 0.0$ \\
\hline $0.62 \mathrm{mg} / \mathrm{mL}$ & $21.0^{\mathrm{a}} \pm 4.5$ & $15.9^{\mathrm{ab}} \pm 18.9$ & $0.0^{\mathrm{a}} \pm 0.0$ & $0.0^{\mathrm{a}} \pm 0.0$ & $0.0^{\mathrm{a}} \pm 0.0$ \\
\hline $1.25 \mathrm{mg} / \mathrm{mL}$ & $64.0^{\mathrm{b}} \pm 6.4$ & $29.2^{b c} \pm 7.2$ & $6.0^{\mathrm{b}} \pm 8.9$ & $4.0^{\mathrm{a}} \pm 4.66$ & $0.0^{\mathrm{a}} \pm 0.0$ \\
\hline $2.0 \mathrm{mg} / \mathrm{mL}$ & $99.0^{c} \pm 2.9$ & $63.7^{c} \pm 6.2$ & $44.0^{b c} \pm 22.9$ & $92.6^{b} \pm 6.31$ & $32.1^{b c} \pm 25.3$ \\
\hline $2.5 \mathrm{mg} / \mathrm{mL}$ & $100.0^{c} \pm 0.0$ & $95.3^{\mathrm{cd}} \pm 3.4$ & $47.0^{\mathrm{bc}} \pm 11.3$ & $100.0^{\mathrm{b}} \pm 0.0$ & $80.4^{\mathrm{cd}} \pm 13.1$ \\
\hline $5.0 \mathrm{mg} / \mathrm{mL}$ & $100.0^{c} \pm 0.0$ & $100.0^{d} \pm 0.0$ & $99.0^{c} \pm 2.8$ & $100.0^{\mathrm{b}} \pm 0.0$ & $96.7^{d} \pm 5.2$ \\
\hline $10.0 \mathrm{mg} / \mathrm{mL}$ & $\ldots$ & $\ldots$ & $100.0^{c} \pm 0.0$ & $\ldots$ & $100.0^{d} \pm 0.0$ \\
\hline
\end{tabular}

Different letters in the same column mean significant differences at the level of 5\%.

*Control Cinnamomum zeylanicum; Eremanthus erythropappus; (E)-cinnamaldehyde and Cinnamyl acetate = 70\% ethanol. Control a-bisabolol = $50 \%$ ethanol; ... = Concentration not tested.

Table 3. Lethal concentrations ( $\mathrm{LC}_{50}$ ) of Cinnamomum zeylanicum, (E)-cinnamaldehyde, cinnamyl acetate, Eremanthus erythropappus and a-bisabolol in Rhipicephalus microplus.

\begin{tabular}{|c|c|c|c|}
\hline & $\mathrm{LC}_{50}(\mathrm{mg} / \mathrm{mL})$ & Confidence interval $(\mathrm{CI})$ & $p$ value \\
\hline \multicolumn{4}{|l|}{ Unengorged larvae } \\
\hline Cinnamomum zeylanicum & 0.94 & $0.50-1.05$ & $<0.01$ \\
\hline (E)-cinnamaldehyde & 1.38 & $1.21-1.58$ & $<0.01$ \\
\hline Cinnamyl acetate & 2.31 & $2.02-2.65$ & $<0.01$ \\
\hline Eremanthus erythropappus & 1.61 & $1.47-1.77$ & $<0.01$ \\
\hline a-bisabolol & 2.20 & $1.92-2.53$ & $<0.01$ \\
\hline \multicolumn{4}{|l|}{ Engorged females } \\
\hline Cinnamomum zeylanicum & 0.57 & $0.10-3.25$ & $<0.01$ \\
\hline (E)-cinnamaldehyde & 1.50 & $0.58-3.86$ & $<0.01$ \\
\hline Cinnamyl acetate & $\cdots$ & $\cdots$ & $\cdots$ \\
\hline Eremanthus erythropappus & 1.93 & $1.0-3.53$ & $<0.01$ \\
\hline a-bisabolol & 6.99 & $6.06-8.05$ & $<0.01$ \\
\hline
\end{tabular}

$\mathrm{Cl}=$ Confidence interval $(95 \%) ; \ldots=$ not calculated.

\section{Adult immersion test}

For C. zeylanicum EO, female weight before oviposition did not differ between treatments $(p>0.05)$. This EO did not result in differences $(p>0.05)$ in egg mass weight between treatments and the control group. The larval hatching rate for the treatment with the lowest concentration $(2.5 \mathrm{mg} / \mathrm{mL})$ was $16.6 \pm 10.1 \%(p<0.05)$, whereas in the control group, larval hatching was $85.4 \pm 7.5 \%$. At the highest concentrations ( 40.0 and $60.0 \mathrm{mg} / \mathrm{mL}$ ), no larvae hatched. The percentage control was $>90 \%$ starting from the $5.0 \mathrm{mg} / \mathrm{mL}$ concentration and reached 99 and $100 \%$ in the treatments with 10.0 and $40.0 \mathrm{mg} / \mathrm{mL}$, respectively (Table 4). 
Table 4. Values for mean weight of females before laying ( $\mathrm{mg}$ ), weight of egg mass of engorged females and larval hatching and percent control of Rhipicephalus microplus, treated with different concentrations of Cinnamomum zeylanicum, (E)-cinnamaldehyde, cinnamyl acetate, Eremanthus erythropappus and a-bisabolol, in laboratory conditions ( $27 \pm 1^{\circ} \mathrm{C}$ and $\left.\mathrm{RH} 80 \pm 10 \%\right)$ (Mean \pm standard deviation).

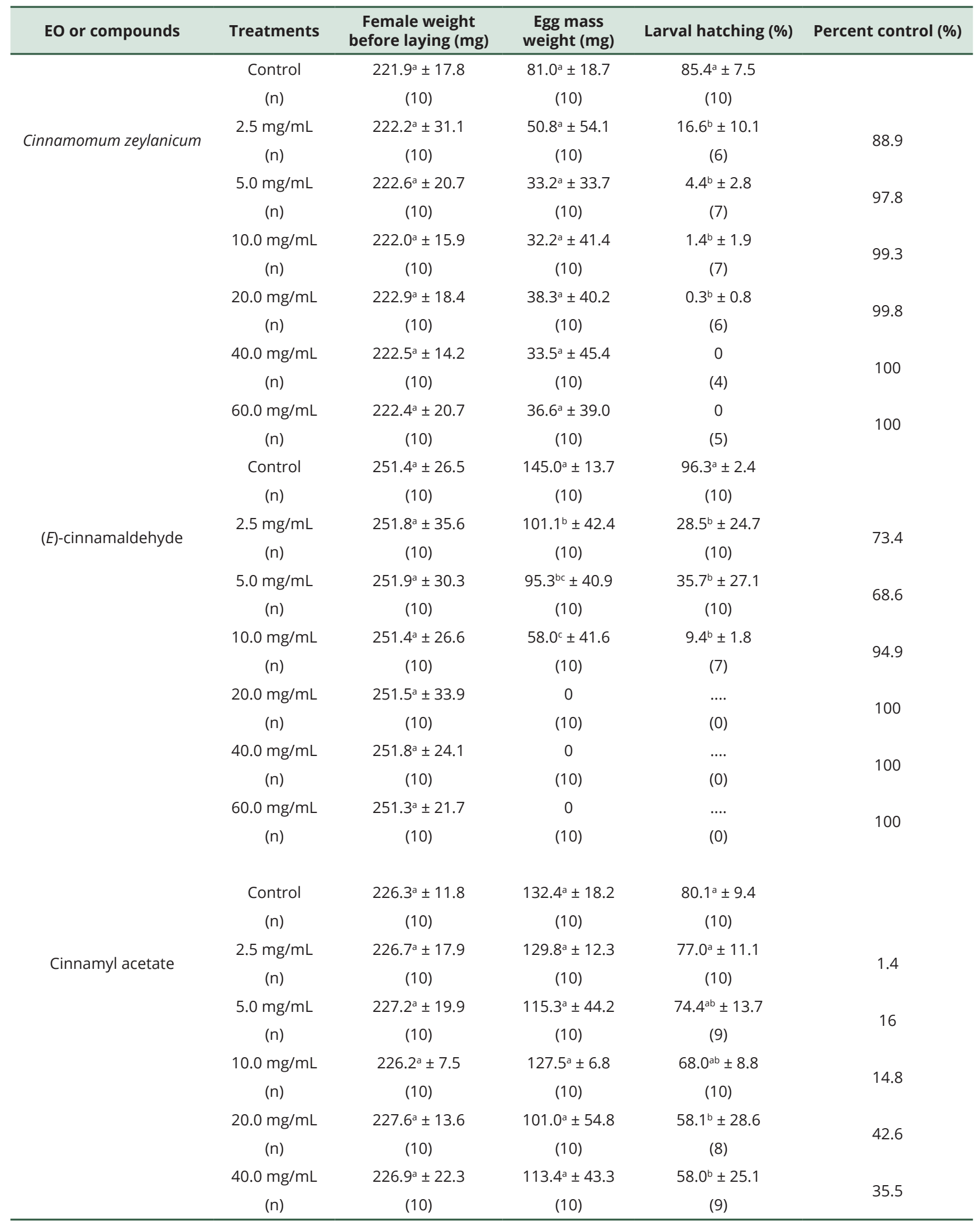

Different letters in the same column mean significant differences at the level of $5 \%$ for the same EO or same compound. $n=$ Sample size; Control $=$ DMSO $3 \%$. 
Table 4. Continued...

\begin{tabular}{|c|c|c|c|c|c|}
\hline EO or compounds & Treatments & $\begin{array}{c}\text { Female weight } \\
\text { before laying (mg) }\end{array}$ & $\begin{array}{c}\text { Egg mass } \\
\text { weight (mg) }\end{array}$ & Larval hatching (\%) & Percent control (\%) \\
\hline \multirow{8}{*}{ Eremanthus erythropappus } & $\begin{array}{c}60.0 \mathrm{mg} / \mathrm{mL} \\
(\mathrm{n})\end{array}$ & $\begin{array}{c}225.5^{a} \pm 16.6 \\
(10)\end{array}$ & $\begin{array}{c}112.7^{a} \pm 41.3 \\
(10)\end{array}$ & $\begin{array}{c}56.6^{b} \pm 8.2 \\
(9)\end{array}$ & 36.2 \\
\hline & $\begin{array}{c}\text { Control } \\
\text { (n) }\end{array}$ & $\begin{array}{c}201.8^{a} \pm 12.8 \\
(10)\end{array}$ & $\begin{array}{c}67.7^{\mathrm{a}} \pm 22.2 \\
(10)\end{array}$ & $\begin{array}{c}84.2^{\mathrm{a}} \pm 12.3 \\
(10)\end{array}$ & \\
\hline & $\begin{array}{c}2.5 \mathrm{mg} / \mathrm{mL} \\
\text { (n) }\end{array}$ & $\begin{array}{c}202.0^{\mathrm{a}} \pm 22.3 \\
(10)\end{array}$ & $\begin{array}{c}49.2^{\mathrm{ab}} \pm 37.3 \\
(10)\end{array}$ & $\begin{array}{c}55.2^{\mathrm{a}} \pm 36.3 \\
(8)\end{array}$ & 52.4 \\
\hline & $\begin{array}{c}5.0 \mathrm{mg} / \mathrm{mL} \\
\text { (n) }\end{array}$ & $\begin{array}{c}201.0^{\mathrm{a}} \pm 11.0 \\
(10)\end{array}$ & $\begin{array}{c}41.2^{\mathrm{ab}} \pm 39.9 \\
(10)\end{array}$ & $\begin{array}{c}39.7^{\mathrm{b}} \pm 32.0 \\
\text { (8) }\end{array}$ & 71.1 \\
\hline & $\begin{array}{c}10.0 \mathrm{mg} / \mathrm{mL} \\
\text { (n) }\end{array}$ & $\begin{array}{c}201.1^{\mathrm{a}} \pm 12.7 \\
(10)\end{array}$ & $\begin{array}{c}21.4^{\mathrm{bc}} \pm 26.2 \\
(10)\end{array}$ & $\begin{array}{c}37.5^{\mathrm{ab}} \pm 29.9 \\
(6)\end{array}$ & 85.9 \\
\hline & $\begin{array}{c}20.0 \mathrm{mg} / \mathrm{mL} \\
(\mathrm{n})\end{array}$ & $\begin{array}{c}201.9^{\mathrm{a}} \pm 18.9 \\
(10)\end{array}$ & $\begin{array}{c}58.3^{a} \pm 30.6 \\
(10)\end{array}$ & $\begin{array}{c}16.5^{b c} \pm 19.7 \\
\text { (8) }\end{array}$ & 83.1 \\
\hline & $\begin{array}{c}40.0 \mathrm{mg} / \mathrm{mL} \\
(\mathrm{n})\end{array}$ & $\begin{array}{c}202.4^{a} \pm 21.7 \\
(10)\end{array}$ & $\begin{array}{c}23.4^{b c} \pm 23.4 \\
(10)\end{array}$ & $\begin{array}{c}11.7^{b} \pm 15.2 \\
\text { (7) }\end{array}$ & 89.9 \\
\hline & $\begin{array}{c}60.0 \mathrm{mg} / \mathrm{mL} \\
(\mathrm{n})\end{array}$ & $\begin{array}{c}202.6^{a} \pm 17.5 \\
(10)\end{array}$ & $\begin{array}{c}2.0^{c} \pm 6.3 \\
(10)\end{array}$ & $\begin{array}{c}0 \\
(1)\end{array}$ & 100 \\
\hline \multirow{7}{*}{ a-bisabolol } & $\begin{array}{c}\text { Control } \\
\text { (n) }\end{array}$ & $\begin{array}{c}251.4^{\mathrm{a}} \pm 26.5 \\
(10)\end{array}$ & $\begin{array}{c}145.0^{\mathrm{a}} \pm 13.7 \\
(10)\end{array}$ & $\begin{array}{c}96.3^{\mathrm{a}} \pm 2.4 \\
(10)\end{array}$ & \\
\hline & $\begin{array}{c}2.5 \mathrm{mg} / \mathrm{mL} \\
(\mathrm{n})\end{array}$ & $\begin{array}{c}251.7^{\mathrm{a}} \pm 20.7 \\
(10)\end{array}$ & $\begin{array}{c}136.0^{\mathrm{a}} \pm 14.7 \\
(10)\end{array}$ & $\begin{array}{c}74.5^{\mathrm{ab}} \pm 16.9 \\
(10)\end{array}$ & 3.2 \\
\hline & $\begin{array}{c}5.0 \mathrm{mg} / \mathrm{mL} \\
(\mathrm{n})\end{array}$ & $\begin{array}{c}251.6^{\mathrm{a}} \pm 26.4 \\
(10)\end{array}$ & $\begin{array}{c}94.6^{\mathrm{ab}} \pm 54.6 \\
(10)\end{array}$ & $\begin{array}{c}47.3^{\mathrm{b}} \pm 33.1 \\
(9)\end{array}$ & 45.6 \\
\hline & $\begin{array}{c}10.0 \mathrm{mg} / \mathrm{mL} \\
(\mathrm{n})\end{array}$ & $\begin{array}{c}251.6^{a} \pm 26.6 \\
(10)\end{array}$ & $\begin{array}{c}76.1^{b} \pm 58.4 \\
(10)\end{array}$ & $\begin{array}{c}47.5^{\mathrm{b}} \pm 23.7 \\
\text { (7) }\end{array}$ & 51.7 \\
\hline & $\begin{array}{c}20.0 \mathrm{mg} / \mathrm{mL} \\
(\mathrm{n})\end{array}$ & $\begin{array}{c}251.6^{\mathrm{a}} \pm 17.9 \\
(10)\end{array}$ & $\begin{array}{c}5.5^{b} \pm 22.9 \\
(10)\end{array}$ & $\begin{array}{c}0 \\
(2)\end{array}$ & 100 \\
\hline & $\begin{array}{c}40.0 \mathrm{mg} / \mathrm{mL} \\
(\mathrm{n})\end{array}$ & $\begin{array}{c}251.3^{\mathrm{a}} \pm 26.3 \\
(10)\end{array}$ & $\begin{array}{c}0.0^{b} \pm 0.0 \\
(10)\end{array}$ & $\begin{array}{l}\ldots . . \\
(0)\end{array}$ & 100 \\
\hline & $\begin{array}{c}60.0 \mathrm{mg} / \mathrm{mL} \\
(\mathrm{n})\end{array}$ & $\begin{array}{c}251.3^{a} \pm 24.6 \\
(10)\end{array}$ & $\begin{array}{c}0.0^{b} \pm 0.0 \\
(10)\end{array}$ & $\begin{array}{l}\cdots \\
(0)\end{array}$ & 100 \\
\hline
\end{tabular}

Different letters in the same column mean significant differences at the level of $5 \%$ for the same EO or same compound. $n=$ Sample size; Control $=$ DMSO $3 \%$.

The egg mass weight of the groups treated with $(E)$-cinnamaldehyde ranged from $101.1 \pm 7.5$ to $0.0 \mathrm{mg}$, which was different $(p<0.05)$ from the value recorded for the control group $(145.0 \pm 13.7 \mathrm{mg})$. Similarly, larval hatching ranged from $28.5 \pm 24.7$ to $9.4 \pm 1.8 \%$ in the treated groups $(p<0.05)$ and was $96.3 \pm 2.4 \%$ in the control group. The percentage control was $73.4 \%$ at the lowest concentration $(2.5 \mathrm{mg} / \mathrm{mL})$ and reached $100.0 \%$ at the concentration of $20.0 \mathrm{mg} / \mathrm{mL}$ (Table 4).

No difference in mean egg mass weight was observed between engorged females in the control and groups treated with cinnamyl acetate $(p>0.05)$. With regard to larval hatching, only the three highest concentrations $(20.0,40.0$ and $60.0 \mathrm{mg} / \mathrm{mL})$ resulted in values lower $(58.1 \pm 28.6,58.0 \pm 25.1$ and $56.6 \pm 8.2 \% ; p<0.05)$ than that observed in the control group $(80.1 \pm 9.4 \%)$. None of the treatments resulted in percentage control $>50 \%$, such that this reached a maximum of $42.6 \%$ at the concentration of $20.0 \mathrm{mg} / \mathrm{mL}$ (Table 4). 
For E. erythropappus EO, starting from the concentration of $10.0 \mathrm{mg} / \mathrm{mL}$, a reduction $(p<0.05)$ in egg mass weight ( $21.4 \pm 26.2 \mathrm{mg}$ ) was observed, in comparison with the control group (67.7 $\pm 22.2 \mathrm{mg}$ ). Regarding larval hatching, there was a difference $(p<0.05)$ between the control $(84.2 \pm 12.3 \%)$ and treated groups, starting from the concentration of $5.0 \mathrm{mg} / \mathrm{mL}$, with values ranging from $39.7 \pm 32.0$ to $0.0 \%$. The percentage control at the $2.5 \mathrm{mg} / \mathrm{mL}$ concentration was $52.4 \%$, and reached $100.0 \%$ at the highest concentration $(60.0 \mathrm{mg} / \mathrm{mL}$ ) (Table 4).

Egg mass weight presented differences $(p<0.05)$ at a-bisabolol concentrations $\geq 10.0 \mathrm{mg} / \mathrm{mL}(76.1 \pm 58.4 \mathrm{mg})$, while the control group showed egg mass weight equal to $145.0 \pm 13.7 \mathrm{mg}$. The a-bisabolol concentration of $5.0 \mathrm{mg} / \mathrm{mL}$ resulted in $47.3 \pm 33.1 \%$ larval hatching, which was different $(p<0.05)$ from the percentage recorded for the control group $(96.3 \pm 2.4 \%$ ). The percentage control reached $100.0 \%$ at a-bisabolol concentrations $\geq 20.0 \mathrm{mg} / \mathrm{mL}$ (Table 4).

The $\mathrm{LC}_{50}$ values for $C$. zeylanicum and E. erythropappus EOs, $(E)$-cinnamaldehyde and a-bisabolol used against R. microplus engorged females were $0.57,1.93,1.50$ and $6.99 \mathrm{mg} / \mathrm{mL}$, respectively. This analysis was not applied to cinnamyl acetate, since the observed control percentage did not reach $50 \%$ (Table 3).

\section{Discussion}

The essential oil extracted from cinnamon bark that was investigated in the present study resulted in $\mathrm{LC}_{50}$ of $0.94 \mathrm{mg} / \mathrm{mL}$ against larvae. A similar result was observed by Jyoti et al. (2019), who evaluated the activity of the essential oil of C. zeylanicum bark (with $64.4 \%$ (E)-cinnamaldehyde) on $R$. microplus larvae, and observed $\mathrm{LC}_{50}$ of $0.86 \mathrm{mg} / \mathrm{mL}$. The small differences found may be related to the chemotype of the plant, unequal percentages and chemical constituents, and to different strains of $R$. microplus.

For engorged females, the present study found a percentage control of $99.8 \%$ at the concentration of $20.0 \mathrm{mg} / \mathrm{mL}$. No reports on the activity of cinnamon bark essential oil against $R$. microplus engorged females were found in the literature. However, Monteiro et al. (2017) reported a percentage control of $27.3 \%$ against $R$. microplus engorged females that were treated with essential oil (with $4.0 \%$ (E)-cinnamaldehyde) extracted from C. zeylanicum leaves at the concentration of $25.0 \mathrm{mg} / \mathrm{mL}$. Santos et al. (2017) reported $100.0 \%$ effectiveness among R. microplus engorged females exposed to commercial cinnamon essential oil (with $41.27 \%$ (E)-cinnamaldehyde) at the concentration of $100.0 \mathrm{mg} / \mathrm{mL}$. Thus, both the data from the present study and the data in the literature indicated that the percentage of this phenylpropanoid in the chemical composition of cinnamon EO had significant influence on its acaricidal activity. This is emphasized by the results regarding activity in the tests with (E)-cinnamaldehyde alone, which showed $\mathrm{LC}_{50}$ of 1.38 and $1.50 \mathrm{mg} / \mathrm{mL}$ for larvae and engorged females, respectively. In the present study, we observed a mortality of $95.3 \%$ of the larvae treated at a concentration of $2.5 \mathrm{mg} / \mathrm{mL}$ of (E)-cinnamaldehyde, corroborating the results found by Senra et al. (2013), which in the same concentration observed a mortality of $99.2 \%$. In future studies on cinnamon oil for tick control, samples extracted from bark, which is rich in this phenylpropanoid, should be prioritized.

R. microplus larvae treated with E. erythropappus EO (with $78.41 \%$ a-bisabolol) at the concentration of $2.0 \mathrm{mg} / \mathrm{mL}$ presented a mortality rate $>90.0 \%$ in the present study. Diniz (2014) evaluated the activity of four Siparuna guianensis EOs and observed that two samples containing the sesquiterpene a-bisabolol (>62.6\%) presented higher activity against $R$. microplus unfed larvae and engorged females than two samples that did not have this compound in their chemical composition. El-Moneim et al. (2012) evaluated the action of Chamomilla recutita (L.) Rauscher essential oil, which is rich in a-bisabolol (35.2\%), on Tetranychus urticae mites and observed a $100.0 \%$ mortality rate at $4.0 \%$ concentration. These results indicate that the presence of the sesquiterpene a-bisabolol is a major factor for the high acaricidal activity observed in these EOs. According to Paluch et al. (2009), sesquiterpenes produced by different plant families can be used to affect the behavior of some arthropods and even kill them. The action of sesquiterpene-rich EOs against ticks has previously been recorded in relation to plants belonging to the families Araucariaceae, Cupressaceae (Lebouvier et al., 2013), Asteraceae (Ribeiro et al., 2011; Lage et al., 2014), Lamiaceae (Facey et al., 2005) and Winteraceae (Ribeiro et al., 2008).

The activity of pure a-bisabolol against $R$. microplus unfed larvae and engorged females was first demonstrated in a study conducted by Diniz (2014), whose results showed a larval mortality rate of $98.9 \%$ at the concentration of $5.0 \mathrm{mg} / \mathrm{mL}$ and a percentage control of $98.1 \%$ among engorged females treated at the concentration of $40.0 \mathrm{mg} / \mathrm{mL}$ (Diniz, 2014). The present study recorded larval mortality of $96.7 \%$ for the pure a-bisabolol concentration of $5.0 \mathrm{mg} / \mathrm{mL}$, and this sesquiterpene resulted in percentage control of $100.0 \%$ at the concentration of $20.0 \mathrm{mg} / \mathrm{mL}$ against engorged females. The different results observed in relation to engorged females may be associated with 
the solvent used. Diniz (2014) used Tween80 as the solvent, whereas DMSO was used in the present study. Studies have shown that certain types of solvent can enhance the effect of EOs (Daemon et al., 2012), and there are data in the literature demonstrating that certain surfactants can reduce the activity of essential oils (Li et al., 2017). In that regard, some studies have shown that DMSO, being hydrophilic, is capable of penetrating cell membranes and carrying the toxic agent with it (Gorman \& Dordick, 1992; Du et al., 2004).

A comparison between the $\mathrm{LC}_{50}$ values of the EOs and their major compounds (cinnamon essential oil vs. (E)-cinnamaldehyde and candeia essential oil vs. a-bisabolol) demonstrated that these EOs showed higher activity against $R$. microplus unfed larvae than their major compounds alone. The candeia essential oil also showed higher activity against engorged females, in comparison with a-bisabolol. The higher activity of EOs may be due to synergistic or additive effects resulting from the association between major compounds and other molecules found in the cinnamon and candeia EOs, which can enhance their acaricidal activity. Monteiro et al. (2017) evaluated a chemotype of the EO of $C$. verum and its major component, benzyl benzoate, against $R$. microplus larvae and also observed that the EO showed better activity. Costa-Júnior et al. (2016) observed the activity of the EO of Lippia gracilis Schauer and the monoterpene thymol against two strains of $R$. microplus (unfed larvae) and observed that, in both strains, the EO resulted in greater activity than the monoterpene thymol.

The (E)-cinnamaldehyde used in the present study showed higher activity than a-bisabolol; therefore, only this phenylpropanoid was used to produce the acetylated derivative (cinnamyl acetate). Cinnamyl acetate presented lower acaricidal activity than $(E)$-cinnamaldehyde in tests conducted using unfed larvae, with $\mathrm{LC}_{50}$ of 2.31 and $1.38 \mathrm{mg} / \mathrm{mL}$ for the larvae. The difference in acaricidal activity was higher in tests conducted using engorged females, since the highest cinnamyl acetate concentration $(60.0 \mathrm{mg} / \mathrm{mL})$ resulted in percentage control of only $36 \%$, while (E)-cinnamaldehyde at a concentration of $20.0 \mathrm{mg} / \mathrm{ml}$ resulted in percentage control of $100.0 \%$. Lee et al. (2019) compared the acaricidal activity of cinnamon bark essential oil with that of (E)-cinnamaldehyde and cinnamyl acetate against Dermanyssus gallinae (De Geer) and found that cinnamyl acetate was the only substance that did not have repellent and acaricidal effects on these mites. Novato et al. (2018) observed that carvacrol, thymol and eugenol presented higher activity against $R$. microplus unfed larvae than their acetylated derivatives. However, there is controversy about the enhancement of acetylated compounds for application to ticks. According to Ramírez et al. (2016), carvacrol showed lower activity against $R$. microplus unfed larvae and engorged females than its acetylated derivative (carvacrol acetate).

All the compounds analyzed in this study significantly reduced the viability of eggs of $R$. microplus engorged females. Other studies evaluated the activity of different phytochemicals on engorged females and also reported significant reductions of egg viability. Marchesini et al. (2020) observed that Jambu extract and spilanthol reduced the egg viability of $R$. microplus, and the same was observed for Baccharis dracunculifolia EO and nerolidol (major compound) (Lage et al., 2014) and Lippia triplinervis EO rich in thymol and carvacrol (Lage et al., 2013), against cattle tick. This reduction in egg viability may be related to action by this EO and its compounds alone, in organs related to the reproductive biology of engorged females, such as the ovaries and Gené's organ. Studies have shown that use of pure constituents of EOs such as thymol and semi-synthetic compound acetylcarvacrol led to a number of morphophysiological changes in engorged females' oocytes, with damage to the nucleus and germinal vesicle, cytoplasm vacuolation, membrane rupture and deformation, and a reduced number of yolk granules (Matos et al., 2014; Konig et al., 2019). In addition, a recent study found that the monoterpene thymol had deleterious action on Gené's organ (Matos et al., 2020). Future studies focused on investigating the action of cinnamon and candeia EOs, as well as the action of (E)-cinnamaldehyde and a-bisabolol on these organs, based on use of morphological analysis tools, could assist in achieving better understanding of the mechanisms capable of reducing the viability of the eggs of engorged females.

We conclude that C. zeylanicum and E. erythropappus EOs, as well as their major compounds, showed acaricidal activity on $R$. microplus unfed larvae and engorged females, while cinnamyl acetate showed low acaricidal activity. In addition, the EOs showed greater activity than their major compounds. The results suggest that some plant compounds are candidates for use as pesticides against green ticks. Further studies to assist in better understanding the possible modes of action of these EOs and their major compounds against $R$. microplus, as well as tests to assess efficacy against ticks and clinical safety for cattle, are necessary. 


\section{References}

Abbas RZ, Zaman MA, Colwell DD, Gilleard J, Iqbal Z. Acaricide resistance in cattle ticks and approaches to its management: the state of play. Vet Parasitol 2014; 203(1-2): 6-20. http://dx.doi.org/10.1016/j.vetpar.2014.03.006. PMid:24709006.

Adams RP. Identification of essential oils components by gas chromatography/mass spectrometry. Carol Stream, IL: Allured Publishing Corporation; 2009.

André WPP, Ribeiro WLC, Cavalcante GS, Santos JML, Macedo ITF, Paula HCB, et al. Comparative efficacy and toxic effects of carvacryl acetate and carvacrol on sheep gastrointestinal nematodes and mice. Vet Parasitol 2016; 218: 52-58. http://dx.doi. org/10.1016/j.vetpar.2016.01.001. PMid:26872928.

André WPP, Cavalcante GS, Ribeiro WLC, Santos JML, Macedo ITF, Paula HCB, et al. Anthelmintic effect of thymol and thymol acetate on sheep gastrointestinal nematodes and their toxicity in mice. Rev Bras Parasitol Vet 2017; 26(3): 323-330. http://dx.doi. org/10.1590/s1984-29612017056. PMid:28977246.

Ayres M, Ayres JM, Ayres DL, Santos AAS. Bioestat 5.0: aplicações estatísticas nas áreas das ciências biológicas e médicas. Belém: Sociedade Civil Mamirauá; 2007.

Bohlmann J, Meyer-Gauen G, Croteau R. Plant terpenoid synthases: molecular biology and phylogenetic analysis. Proc Natl Acad Sci USA 1998; 95(8): 4126-4133. http://dx.doi.org/10.1073/pnas.95.8.4126. PMid:9539701.

Borges LMF, Sousa LAD, Barbosa CS. Perspectives for the use of plant extracts to control the cattle tick Rhipicephalus (Boophilus) microplus. Rev Bras Parasitol Vet 2011; 20(2): 89-96. http://dx.doi.org/10.1590/S1984-29612011000200001. PMid:21722481.

Carmo ES, Lima EO, Souza EL, Sousa FB. Effect of Cinnamomum zeylanicum blume essential oil on the growth and morphogenesis of some potentially pathogenic Aspergillus species. Braz J Microbiol 2008; 39(1): 91-97. http://dx.doi.org/10.1590/S151783822008000100021. PMid:24031186.

Costa-Júnior LM, Miller RJ, Alves PB, Blank AF, Li AY, Pérez de León AA. Acaricidal efficacies of Lippia gracilis essential oil and its phytochemicals against organophosphate-resistant and susceptible strains of Rhipicephalus (Boophilus) microplus. Vet Parasitol 2016; 228: 60-64. http://dx.doi.org/10.1016/j.vetpar.2016.05.028. PMid:27692332.

Daemon E, Maturano R, Monteiro CMO, Goldner MS, Massoni T. Acaricidal activity of hydroethanolic formulations of thymol against Rhipicephalus sanguineus (Acari: Ixodidae) and Dermacentor nitens (Acari: Ixodidae) larvae. Vet Parasitol 2012; 186(3-4): 542-545. http://dx.doi.org/10.1016/j.vetpar.2011.11.013. PMid:22137349.

Diniz JÁ. Siparuna guianensis Aublet como nova fonte de a-bisabolol para o controle de Rhipicephalus microplus [dissertação]. Viçosa: Universidade Federal de Viçosa; 2014.

Drummond RO, Ernst SE, Trevino JL, Gladney WJ, Graham OH. Boophilus annulatus and B. microplus: laboratory tests of insecticides. J Econ Entomol 1973; 66(1): 130-133. http://dx.doi.org/10.1093/jee/66.1.130. PMid:4690254.

Du W, Xu Y, Liu D, Zeng J. Comparative study on lipase-catalyzed transformation of soybean oil for biodiesel production with different acyl acceptors. J Mol Catal, B Enzym 2004; 30(3-4): 125-129. http://dx.doi.org/10.1016/j.molcatb.2004.04.004.

El-Moneim MRAA, Ali FS, Turky AF. Control of Tetranychus urticae Koch by extracts of three essential oils of chamomile, marjoram and Eucalyptus. Asian Pac J Trop Biomed 2012; 2(1): 24-30. http://dx.doi.org/10.1016/S2221-1691(11)60184-6. PMid:23569829.

El-Sayed AM. The Pherobase: Database of Insect Pheromones and Semiochemicals. Epi Info [online]. 2018 [cited 2019 Jan 3]. Available from: http://www.pherobase.com/

Facey PC, Porter RBR, Reese PB, Williams LAD. Biological activity and chemical composition of the essential oil from Jamaican Hyptis verticillata Jacq. J Agric Food Chem 2005; 53(12): 4774-4777. http://dx.doi.org/10.1021/jf050008y. PMid:15941314.

Furlong J, Martins JR, Prata MCA. O carrapato dos bovinos e a resistência: temos o que comemorar? Hora Vet 2007; $27: 1$-7.

Gorman LAS, DordickJS. Organic solvents strip water off enzymes. Biotechnol Bioeng 1992; 39(4): 392-397. http://dx.doi.org/10.1002/ bit.260390405. PMid:18600960.

GrafJF, Gogolewski R, Leach-Bing N, Sabatini GA, Molento MB, Bordin EL, et al. Tick control: an industry point of view. Parasitology 2004;129(Suppl. 1): S427-S442. http://dx.doi.org/10.1017/S0031182004006079. PMid:15938522.

Grisi L, Leite RC, Martins JR, Barros AT, Andreotti R, Cançado PHD, et al. Reassessment of the potential economic impact by cattle parasites in Brazil. Rev Bras Parasitol Vet 2014; 23(2): 150-156. http://dx.doi.org/10.1590/S1984-29612014042. PMid:25054492.

Jyoti, Singh NK, Singh H, Mehta N, Rath SS. Jyoti, Singh NK, Singh H, Mehta N, Rath SS. In vitro assessment of synergistic combinations of essential oils against Rhipicephalus (Boophilus) microplus (Acari: ixodidae). Exp Parasitol 2019; 201: 42-48. http:// dx.doi.org/10.1016/j.exppara.2019.04.007. PMid:31034814.

Kamatou GPP, Viljoen AM. A review of the application and pharmacological properties of a-bisabolol and a-bisabolol- rich oils. J Am Oil Chem Soc 2010; 87(1): 1-7. http://dx.doi.org/10.1007/s11746-009-1483-3. PMid:21350591. 
Kim E, Moore BS, Yoon YJ. Reinvigorating natural product combinatorial biosynthesis with synthetic biology. Nat Chem Bio/ 2015; 11(9): 649-659. http://dx.doi.org/10.1038/nchembio.1893. PMid:26284672.

Konig IFM, Gonçalves RRP, Oliveira MVS, Silva CM, Thomasi SS, Peconick AP, et al. Sublethal concentrations of acetylcarvacrol strongly impact oocyte development of engorged female cattle ticks Rhipicephalus microplus (Canestrini, 1888) (Acari: ixodidae). Ticks Tick Borne Dis 2019; 10(4): 766-774. http://dx.doi.org/10.1016/j.ttbdis.2019.03.010. PMid:30904538.

Labruna MB, Machado RZ. Agentes transmitidos por carrapatos na região neotropical. In: Barros-Battesti DMB, Arzua M, Bechara GH, editors. Carrapatos de importância médico-veterinária da Região Neotropical: um guia ilustrado para a identificação de espécies. São Paulo: Instituto Butantan; 2006. p. 155-164.

Lage TCA, Montanari RM, Fernandes SA, Monteiro CMO, Senra TOS, Zeringota V, et al. Activity of essential oil of Lippia triplinervis Gardner (Verbenaceae) on Rhipicephalus microplus (Acari: ixodidae). Parasitol Res 2013; 112(2): 863-869. http://dx.doi.org/10.1007/ s00436-012-3209-y. PMid:23224609.

Lage TCA, Montanari RM, Fernandes SA, Monteiro CMO, Senra TOS, Zeringota V, et al. Chemical composition and acaricidal activity of the essential oil of Baccharis dracunculifolia De Candole (1836) and its constituents nerolidol and limonene on larvae and engorged females of Rhipicephalus microplus (Acari: ixodidae). Exp Parasitol 2014; 148: 24-29. http://dx.doi.org/10.1016/j. exppara.2014.10.011. PMid:25448290.

Lanusse CE, Prichard RK. Relationship between pharmacological properties and clinical efficacy of ruminant anthelmintics. Vet Parasitol 1993; 49(2-4): 123-158. http://dx.doi.org/10.1016/0304-4017(93)90115-4. PMid:8249240.

Lebouvier N, Hue T, Hnawia E, Lesaffre L, Menut C, Nour M. Acaricidal activity of essential oils from five endemic conifers of New Caledonia on the cattle tick Rhipicephalus (Boophilus) microplus. Parasitol Res 2013; 112(4): 1379-1384. http://dx.doi.org/10.1007/ s00436-012-3268-0. PMid:23371495.

Lee SJ, Kim HK, Kim GH. Toxicity and effects of essential oils and their components on Dermanyssus gallinae (Acari: dermanyssidae). Exp Appl Acarol 2019; 78(1): 65-78. http://dx.doi.org/10.1007/s10493-019-00363-7. PMid:31069572.

Leite GO, Leite LHI, Sampaio RS, Araruna MKA, Menezes IRA, Costa JGM, et al. (-)-a-bisabolol attenuates visceral nociception and inflammation in mice. Fitoterapia 2011; 82(2): 208-211. http://dx.doi.org/10.1016/j.fitote.2010.09.012. PMid:20875845.

Lew-Tabor AE, Rodriguez Valle M. A review of reverse vaccinology approaches for the development of vaccines against ticks and tick borne diseases. Ticks Tick Borne Dis 2016; 7(4): 573-585. http://dx.doi.org/10.1016/j.ttbdis.2015.12.012. PMid:26723274.

Li J, Chang JW, Saenger M, Deering A. Thymol nanoemulsions formed via spontaneous emulsification: physical and antimicrobial properties. Food Chem 2017; 232: 191-197. http://dx.doi.org/10.1016/j.foodchem.2017.03.147. PMid:28490064.

Liu BB, Chen B, Zhang J, Wang P, Feng G. The environmental fate of thymol, a novel botanical pesticide, in tropical agricultural soil and water. Toxicol Environ Chem 2017; 99(2): 223-232. http://dx.doi.org/10.1080/02772248.2016.1198907.

Madzimure J, Nyahangare ET, Hamudikuwanda H, Hove T, Stevenson PC, Belmain SR, et al. Acaricidal efficacy against cattle ticks and acute oral toxicity of Lippia javanica (Burm F.) Spreng. Trop Anim Health Prod 2011; 43(2): 481-489. http://dx.doi.org/10.1007/ s11250-010-9720-1. PMid:20978842.

Marchesini P, Barbosa AF, Sanches MNG, Nascimento RM, Vale FL, Fabri RL, et al. Acaricidal activity of Acmella oleracea (Asteraceae) extract against Rhipicephalus microplus: what is the influence of spilanthol? Vet Parasitol 2020; 283: 109170. http://dx.doi. org/10.1016/j.vetpar.2020.109170. PMid:32580072.

Mathela CS, Singh KK, Gupta VK. Synthesis and in vitro antibacterial activity of thymol and carvacrol derivatives. Acta Pol Pharm 2010; 67(4): 375-380. PMid:20635533.

Matos RS, Daemon E, Camargo-Mathias MI, Furquim KCS, Sampieri BR, Remedio RN, et al. Histopathological study of ovaries of Rhipicephalus sanguineus (Acari: Ixodidae) exposed to different thymol concentrations. Parasitol Res 2014; 113(12): 4555-4565. http://dx.doi.org/10.1007/s00436-014-4145-9. PMid:25300417.

Matos RS, Oliveira PR, Coelho L, Paula LGF, Zeringota V, Silva BC, et al. Thymol: effects on reproductive biology and Gene's organ morphology in Rhipicephalus sanguineus sensu lato engorged females (Acari: Ixodidae). Ticks Tick Borne Dis 2020; 11 (1): 101308. http://dx.doi.org/10.1016/j.ttbdis.2019.101308. PMid:31640939.

Mishra AK, Mishra A, Bhargava A, Pandey AK. Antimicrobial activity of essential oils from the leaves of Cinnamomum spp. Natl Acad Sci Lett 2008; 31(11): 341-345.

Monteiro CMO, Maturano R, Daemon E, Catunda-Junior FEA, Calmon F, Senra TOS, et al. Acaricidal activity of eugenol on Rhipicephalus microplus (Acari: Ixodidae) and Dermacentor nitens (Acari: Ixodidae) larvae. Parasitol Res 2012; 111(3): 1295-1300. http://dx.doi.org/10.1007/s00436-012-2964-0. PMid:22622689.

Monteiro IN, Monteiro ODS, Costa-Junior LM, da Silva LA, Andrade EHA, Maia JGS, et al. Chemical composition and acaricide activity of an essential oil from a rare chemotype of Cinnamomum verum Presl on Rhipicephalus microplus (Acari: ixodidae). Vet Parasitol 2017; 238: 54-57. http://dx.doi.org/10.1016/j.vetpar.2017.03.016. PMid:28342670. 
Novato T, Gomes GA, Zeringóta V, Franco CT, de Oliveira DR, Melo D, et al. In vitro assessment of the acaricidal activity of carvacrol, thymol, eugenol and their acetylated derivatives on Rhipicephalus microplus (Acari: ixodidae). Vet Parasitol 2018; 260: 1-4. http:// dx.doi.org/10.1016/j.vetpar.2018.07.009. PMid:30197007.

Novato TPL, Araújo LX, Monteiro CMO, Maturano R, Senra TOS, Matos RS, et al. Evaluation of the combined effect of thymol, carvacrol and (E)-cinnamaldehyde on Amblyomma sculptum (Acari: Ixodidae) and Dermacentor nitens (Acari: Ixodidae) larvae. Vet Parasitol 2015; 212(3-4): 331-335. http://dx.doi.org/10.1016/j.vetpar.2015.08.021. PMid:26346899.

Nwanade CF, Wang M, Wang T, Zhang X, Zhai Y, Zhang S, et al. The acaricidal activity of cinnamon essential oil: current knowledge and future perspectives. Int J Acarol 2021; 47(5): 446-450. http://dx.doi.org/10.1080/01647954.2021.1936632.

Oliveira MCC, Carvalho MG, Ferreira DT, Braz-Filho R. Flavonóides das flores de Stiffitia chrysantha Mikan. Quim Nova 1999; 22(2): 182-184. http://dx.doi.org/10.1590/S0100-40421999000200006.

Paluch GE, Zhu J, Bartholomay L, Coats RJ. Amyris and siam-wood essential oils: insect activity of sesquiterpenes. In: Paluch GE, Zhu J, Bartholomay L, Coats RJ, editors. Pestic househ struct resid pest manag. Iowa: Iowa State University Digital Repository; 2009. p. 5-18. https://doi.org/10.1021/bk-2009-1015.ch002.

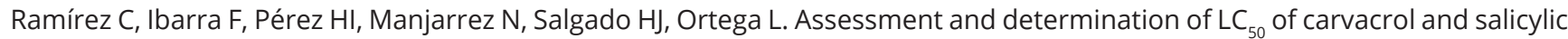
acid analogues with acaricide activity in larvae and adult ticks of Rhipicephalus (Boophilus) microplus. Parasite Epidemiol Control 2016; 1(2): 72-77. http://dx.doi.org/10.1016/j.parepi.2016.02.006. PMid:29988173.

Ribeiro VLS, Santos JC, Martins JR, Schripsema J, Siqueira IR, von Poser GL, et al. Acaricidal properties of the essential oil and precocene II obtained from Calea serrata (Asteraceae) on the cattle tick Rhipicephalus (Boophilus) microplus (Acari: ixodidae). Vet Parasitol 2011; 179(1-3): 195-198. http://dx.doi.org/10.1016/j.vetpar.2011.02.006. PMid:21402447.

Ribeiro VLS, Rolim V, Bordignon S, Henriques AT, Dorneles GG, Limberger RP, et al. Chemical composition and larvicidal properties of the essential oils from Drimys brasiliensis Miers (Winteraceae) on the cattle tick Rhipicephalus (Boophilus) microplus and the brown dog tick Rhipicephalus sanguineus. Parasitol Res 2008; 102(3): 531-535. http://dx.doi.org/10.1007/s00436-007-0799-x. PMid:18046578.

Santos DS, Boito JP, Santos RCV, Quatrin PM, Ourique AF, Reis JH, et al. Nanostructured cinnamon oil has the potential to control Rhipicephalus microplus ticks on cattle. Exp Appl Acarol 2017; 73(1): 129-138. http://dx.doi.org/10.1007/s10493-017-0171-5. PMid:28852887.

Scotti L, Scotti MT, Silva VB, Santos SRL, Cavalcanti SCH, Mendonça FBM Jr. Chemometric studies on potential larvicidal compounds against Aedes aegypti. Med Chem 2014; 10(2): 201-210. http://dx.doi.org/10.2174/15734064113099990005. PMid:23676010.

Senra TOS, Zeringóta V, Monteiro CMO, Calmon F, Maturano R, Gomes GA, et al. Assessment of the acaricidal activity of carvacrol, (E)-cinnamaldehyde, trans-anethole, and linalool on larvae of Rhipicephalus microplus and Dermacentor nitens (Acari: ixodidae). Parasitol Res 2013; 112(4): 1461-1466. http://dx.doi.org/10.1007/s00436-013-3289-3. PMid:23354938.

Shen F, Xing M, Liu L, Tang X, Wang W, Wang X, et al. Efficacy of trans-cinnamaldehyde against Psoroptes cuniculi in vitro. Parasitol Res 2012; 110(4): 1321-1326. http://dx.doi.org/10.1007/s00436-012-2816-y. PMid:22350671.

Stone BF, Haydock KP. A method for measuring the acaricide susceptibility of the cattle tick Boophilus microplus (Can). Bull Entomol Res 1962; 53(3): 563-578. http://dx.doi.org/10.1017/S000748530004832X.

Teixeira JG, Latorraca JVF, Trevisan H, Pae JB. Effiency of neem oil and Eremanthus erythropappus residues on the xylophagus fungi inihibition. Sci For 2015; 43(106): 417-426.

van Den Dool H, Kratz PD. A generalization of the retention index system including linear temperature programmed gas-liquid partition chromatography. J Chromatogr A 1963; 11: 463-471. http://dx.doi.org/10.1016/S0021-9673(01)80947-X. PMid:14062605.

Yang YC, Lee HS, Lee SH, Clark JM, Ahn YJ. Ovicidal and adulticidal activities of Cinnamomum zeylanicum bark essential oil compounds and related compounds against Pediculus humanus capitis (Anoplura: pediculicidae). Int J Parasitol 2005; 35(14): 1595-1600. http://dx.doi.org/10.1016/j.ijpara.2005.08.005. PMid:16188263.

Zaman MA, Iqbal Z, Abbas RZ, Khan MN, Muhammad G, Younus M, et al. In vitro and in vivo acaricidal activity of an herbal extract. Vet Parasitol 2012; 186(3-4): 431-436. http://dx.doi.org/10.1016/j.vetpar.2011.11.018. 